\title{
Cikkismertetés: Gyakrabban járunk gyorsétterembe, ha több található belőlük a környéken?
}

\author{
Article review: Do we go to a fast food restaurant more often \\ if there are more of them in the area?
}

$\begin{array}{ll}\text { Ismertető: } & \text { Devosa Iván } \ \\ & \text { Károli Gáspár Református Egyetem, Tanítóképző Főiskolai Kar, Egészségtudományi } \\ & \text { Kutatómühely, Kecskemét }\end{array}$

Ismertetett cikk: Rongen S., Poelman P- M., Thornton L., et al.: Neighbourhood fast food exposure and consumption: the mediating role of neighbourhood social norms Rongen et al. International Journal of Behavioral Nutrition and Physical Activity (2020) 17:61 https://doi.org/10.1186/s12966-020-00969-w

Beküldve: $\quad$ 2020. 10. 25.

doi: $\quad$ 10.24365/ef.v61i4.648

Kulcsszavak: lakóhely; élelmiszerkörnyezet; gyorséttermek; társadalmi normák

Keywords: neighbourhood; food environment; fast food outlets; social norms

\section{HÁTTÉR}

Egyre nagyobb figyelmet kap a lakóhely gyorséttermi környezete és az étrend közötti kapcsolat. Mindezek ellenére kevésbé vizsgált terület, hogy az élelmiszer fogyasztását miért és hogyan befolyásolja a környezet. A tanulmány célja az volt, hogy megvizsgálja, a lakóhelyen mennyire befolyásolják a lakóhelyi társadalmi normák a gyorséttermi fogyasztást, azaz hogy mi az összefüggés a gyorséttermek helyi lakosokra gyakorolt külső hatása és lakosok gyorséttermi fogyasztása között.

\section{MÓDSZER}

A felmérés országos mintán készült, 1038 holland lakos bevonásával, amely során a megkérdezettek beszámoltak a gyorséttermi fogyasztásukról (heti mennyiség), valamint a környékükön jellemző, a gyorséttermi fogyasztásra vonatkozó, vélt előíró és leíró normákról. (Az előíró norma működésének az alapja, hogy a személy mennyire hajlandó együttmúködni a társas elvárásokkal a szankciók elkerülése érdekében, míg a leíró norma során mások viselkedését figyeljük meg, amely kulcsként szolgálhat a viselkedés megvalósításához, így a viselkedés követésére ösztönözhet. ${ }^{1} \mathrm{~A}$ gyorséttermek viselkedésbefolyásoló hatását a válaszadók irányítószám alapján megállapított lakóhelye körüli 400 méteres sétára lévő gyorséttermek átlagos számával mérték a kiskereskedelmi adatbázis segítségével. [1. ábra] Regressziós modelleket alkalmaztak a lakossági gyorséttermek viselkedésbefolyásoló hatása, a gyorséttermi fogyasztás és a társadalmi normafelfogás közötti összefüggések értékelésére, és a közvetett - mediációs - hatás tesztelésére egy úgynevezett Bootstrap eljárás (közvetett hatások megbízhatósági intervallumainak kiszámítására szolgál) segítségével. Külön elemzéseket végeztek az előíró és a leíró normákra vonatkozóan is. 
1. ábra: Openstreetmap: a 400 m-es sétával elérhetö terület egy adott cím körül. A fekete pontok a gyorséttermeket mutatják.

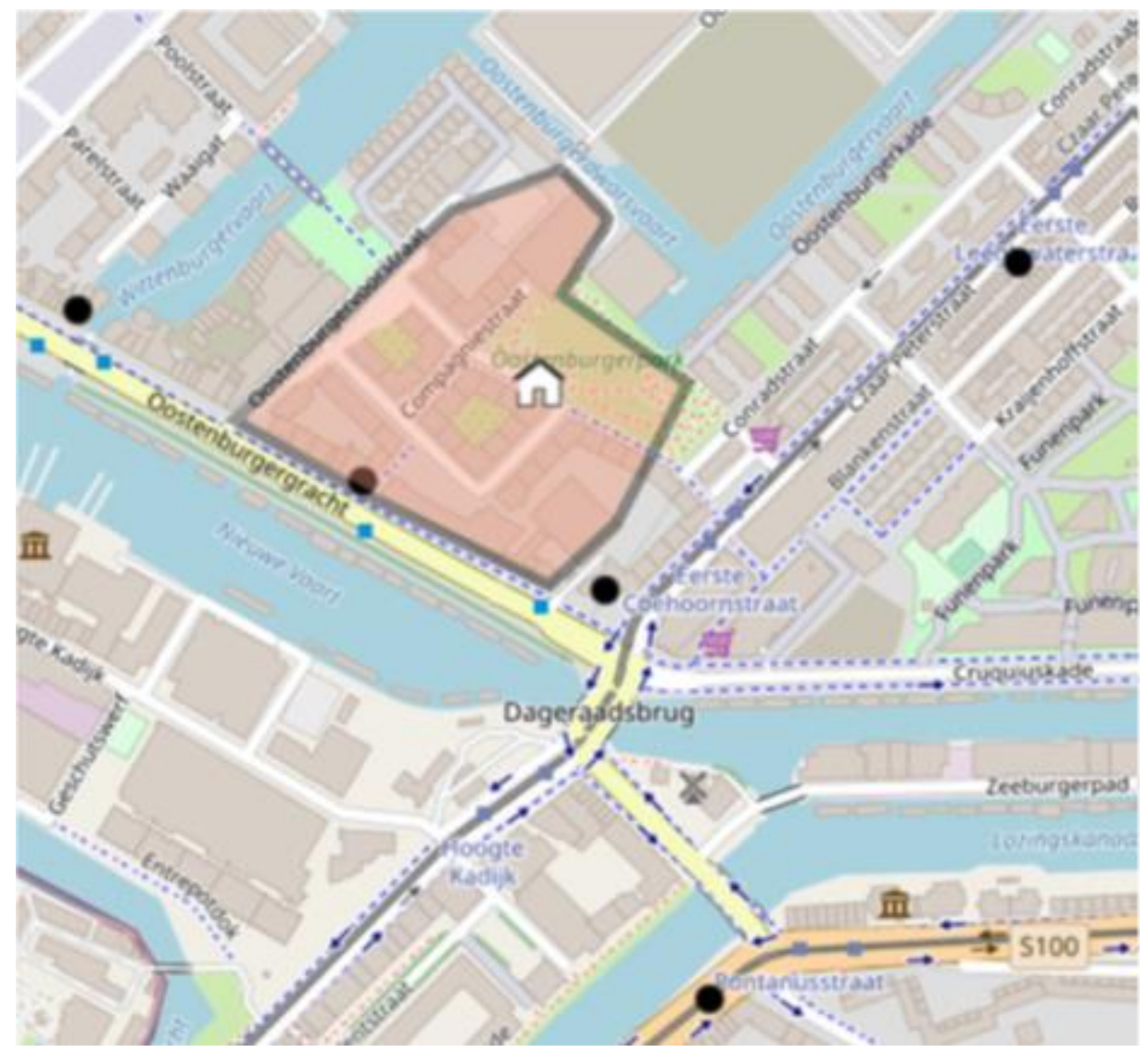

Forrás: saját szerkesztés az eredeti változat alapján

\section{EREDMÉNYEK}

Nem volt általános vagy közvetlen összefüggés a gyorséttermek elérhetősége és a lakosok gyorséttermi fogyasztása között. A gyorséttermek elérhetősége a fogyasztásnövelő hatását a lakóhelyi leíró és előíró normákon keresztül, közvetetten fejti ki, ami pozitív irányú összefüggést mutatott a gyorséttermi fogyasztás esélyével. Ezen túlmenően a bootstrapping elemzés eredményei bizonyítékot szolgáltattak arra vonatkozóan, hogy a gyorséttermek viselkedésbefolyásoló hatása közvetett hatást gyakorol a leíró normák és előíró normákra a gyorséttermi fogyasztás révén.

\section{KÖVETKEZTETÉSEK}

A több gyorséttermi üzlettel rendelkező negyedekben a lakosok nagyobb valószínúséggel érzékelték elfogadottnak, megszokottnak a gyorséttermi fogyasztást. Ebből adódóan erősebb lakóhelybeli szociális normák a megnövekedett gyorséttermi fogyasztással jártak együtt. A kutatás korrelációs elrendezését figyelembe véve ez a tanulmány az első, amely rámutat, hogy a lakóközösségi társadalmi normák közvetítő szerepet tölthetnek be a lakóhelyi gyorséttermi környezet és a lakossági gyorséttermi fogyasztás közötti kapcsolatban. A jövőbeli kutatások fényt deríthetnek arra, hogy a lakóközösségi normák milyen szerepet töltenek be más kapcsolati rendszerekben, valamint hogy a változó élelmiszerkörnyezet hogyan változtathatja meg fogyasztási szokásainkat. 


\section{TANULSÁGOK A HAZAI SZAKEMBEREK SZÁMÁRA}

A hollandiai kutatás eredményei Magyarországon is jól hasznosíthatóak, hiszen a cikk szerzőinek megállapítása, miszerint a (lakó)környezet erősen befolyásolja a fogyasztást, beleérve az egészséges-egészségtelen élelmiszerek arányát, lehetővé teszi, hogy a szakemberek tudatosan tervezzenek olyan körülményeket, melyek a fogyasztókat a jobb minőségú élelmiszerek fogyasztásának irányába terelik: több, hagyományos ételajánlatot kínáló étterem a közelben stb. Mindezt akár úgy is írhatnánk, hogy ami „kicsiben” megvalósul a közoktatási intézményekben, azt „nagyban” a lakóhelyeken is szükséges megteremteni.

\section{HIVATKOZÁSOK}

\footnotetext{
${ }^{1}$ Berkes Tímea (2015) A szándéktól az önszabályozásig. A viselkedés előrejelzésének modelljei egészségviselkedések esetében. Mentálhigiéné és Pszichoszomatika 16. 2, 115-158. DOI: 10.1556/0406.16.2015.2.1
} 